\title{
Microhardness in pressing layers of prefabricated modified acrylic resin teeth
}

\author{
Microdureza nas camadas de prensagem de dentes pré-fabricados em resina acrílica modificada
}

Ricardo dos Santos BAPTISTA'

Gustavo Duarte MENDES²

Milton Edson MIRANDA'

Cecilia Pedroso TURSSI ${ }^{1}$

\section{ABSTRACT}

\section{Objective}

The aim of this study was to evaluate the microhardness in pressing layers of prefabricated modified acrylic resin teeth.

\section{Methods}

Lower first molar teeth with two (Biotone ${ }^{\circledR} I P N$ and Bioform ${ }^{\circledR}$ ) or three pressing layers (Artiplus ${ }^{\circledR}$, Trilux ${ }^{\circledR}$ Eurovipi, and Natusdent ${ }^{\circledR}$ ) were hemisected in a bucco-lingual plane and embedded in a self-curing acrylic resin $(n=10)$. Specimens were then ground flat and polished using 400, 600 and 1200 aluminium oxide paper in a rotatory polisher. In each pressing layer, microhardness was measured using a Knoop indenter in three different locations spaced $300 \mu \mathrm{m}$ apart under a 10-g load, applied for $5 \mathrm{sec}$.

\section{Results}

Analysis of variance and Tukey's tests demonstrated that there was no difference in microhardness in the first layer of the teeth analyzed ( $p=$ 0.355), whereas in the second layer, the brand Artiplus ${ }^{\circledR}$ showed higher values when compared to the brand Natusdent $t^{\circledR}(p=0.018)$. For the third layer, the brands Artiplus ${ }^{\circledR}$ and Trilux $x^{\circledR}$ Eurovipi revealed higher microhardness when compared to Natusdent ${ }^{\circledR}$ teeth $(p<0.001)$.

\section{Conclusion}

For the outer most superficial layer of the artificial teeth, the microhardness of the different brands was similar, while differences were noted for the second and third layers among the artificial teeth, with Artiplus ${ }^{\circledR}$ teeth showing higher microhardness than Natusdent ${ }^{\circledR}$.

Indexing terms: Artificial tooth. Acrylic resins. Hardness tests.

\section{RESUMO}

\section{Objetivo}

Avaliar a microdureza nas camadas de prensagem de dentes fabricados em resina acrílica modificada.

\section{Métodos}

Primeiros molares inferiores pré-fabricados com duas (Biotone ${ }^{\circledR}$ IPN e Bioform ${ }^{\circledR}$ ) ou três camadas de prensagem (Artiplus ${ }^{\circledR}$, Trilux ${ }^{\circledR}$ Eurovipi e Natusdent ${ }^{\circledR}$ ), foram hemisseccionados no sentido vestíbulo-lingual e embutidos em resina acrílica autopolimerizável $(n=10)$. Os espécimes foram, então, planificados e polidos com lixas de óxido de alumínio nas granulações 400, 600 e 1200, em politriz giratória. Em cada camada de prensagem, a microdureza foi mensurada utilizando indentador Knoop em três diferentes localizações, espaçadas em 300 um, sob carga de $10 \mathrm{~g}$, aplicada por $5 \mathrm{~s}$.

\section{Resultados}

Análises de variância e testes de Tukey demonstraram que os dentes avaliados não apresentaram diferenças de microdureza na primeira camada $(p=0,355)$, enquanto na segunda, os dentes da marca Artiplus ${ }^{\circledR}$ revelaram valores superiores em relação aos dentes da marca Natusdent ${ }^{\circledR}$ $(p=0,018)$. Na terceira camada, os dentes da marca Artiplus ${ }^{\circledR}$ e Trilux ${ }^{\circledR}$ Eurovipi apresentaram microdureza superior àquela verificada para os dentes Natusdent ${ }^{\circledR}(p<0,001)$.

\section{Conclusão}

Na camada externa, mais superficial, a microdureza dos dentes artificiais foi semelhante nas diferentes marcas. Apenas nas segunda e terceira camadas houve diferenças entre as marcas de dentes artificiais, sendo que os dentes da Artiplus ${ }^{\circledR}$ apresentaram microdureza superior aos dentes Natusdent ${ }^{\circledR}$.

Termos de indexação: Dente artificial. Resinas acrílicas. Testes de dureza.

\footnotetext{
${ }^{1}$ Faculdade São Leopoldo Mandic, Curso de Odontologia, Programa de Pós-Graduação em Prótese Dentária. Rua José Rocha Junqueira, 13, Swift, 13045-755, Campinas, SP, Brasil. Correspondência para / Correspondence to: RS BAPTISTA. E-mail: <ricardo.odontologia@hotmail.com>.

${ }^{2}$ Universidade Camilo Castelo Branco, Curso de Odontologia. São Paulo, SP, Brasil.
} 


\section{INTRODUCTION}

Artificial acrylic resin teeth were introduced in dentistry in $1940^{1}$ and are still used nowadays, due to their good esthetics, bonding to the resin from the prosthesis, ease of esthetical and functional adjustments when making full removable dentures, as well as polishing when compared to porcelain teeth ${ }^{2-4}$.

One of the most important mechanical properties of artificial teeth used for rehabilitation of the edentulous patients is wear resistance, which is important in the context of maintenance of a stable occlusal relationship for long periods of time when using removable partial or full dentures as well as overdentures.

Tooth wear changes the occlusal vertical dimension $(O V D)$, reducing the efficiency of mastication, undermining esthetics, increasing stress on the supporting structures, leading to bone resorption and discomfort, which could be associated to temporomandibular joint (TMJ) disorders (ATM) ${ }^{3,5-6}$

Restoring OVD is one of the great challenges in dentistry and its maintenance is compromised by artificial teeth wear during mastication and speech. Therefore, an important consideration in the process of OVD restoration is the selection of teeth. The lattermust have physical and mechanical properties to aid in maintaining the OVD, therefore, careful attention to the opposing dentition can also play an important role? .

There are three types of materials that are commonly used to make artificial posterior teeth: ceramic, resin and metal. Porcelain teeth are regarded as superior in terms of wear, however limitations such as poor bonding to the base of the denture, the sound generated during mastication, their abrasive effect on the opposing teeth and the difficulty to adjust occlusion should be taken into account ${ }^{7}$. On the other hand, artificial teeth with metallic occlusal surfaces present good properties in terms of OVD maintenance, especially when the opposing arch contains metallic restorations or even natural enamel, however, the increased number of laboratory steps and consequently higher costs, as well as the esthetic compromise limit their use. Resin teeth, however, present advantages such as adhesion to the base material of the denture, excellent impact absorption, they are passive to occlusal adjustment and polishing. Nevertheless, their most important disadvantage is their low wear resistance ${ }^{7}$.

New materials have, therefore, been introduced as alternatives to the conventional acrylic resin teeth, such as interpenetrating network (IPN) acrylic resin, composite resin with micro-particles and SLM (sustained life material). It has been suggested that such materials have a higher wear resistance than the conventional acrylic resin and without those limitations inherent of porcelain teeth. In fact, clinical observation reveals differences in wear on artificial teeth made from modified acrylic resin from different manufacturers ${ }^{8}$. Considering the aforementioned arguments, the purpose of this study was to evaluate the microhardness of such teeth in their different pressing layers.

\section{METHODS}

Five commercial brands of artificial teeth were selected (Chart 1). Only lower first molars were used $(n=10)$, which were hemisected in the bucco-lingual direction using a carborundum disk (Carboril) at low speed. One hemisected piece from each tooth was embedded in 3/4-inch PVC tubes containing self-polymerizing acrylic resin.

The specimen obtained wasground flat and polished using aluminum oxide sandpaper in decreasing grain (400, 600 and 1200) mounted on a rotatory polisher (Aropol 2V, Arotec). Knoop hardness was measured using a digital microharness tester (HVS-1000, Pantec) equipped with a Knoop indenter, and set for a static load of $10 \mathrm{~g}$ applied for $5 \mathrm{sec}$.

Following visual inspection of the artificial teeth layers under 10X magnification, three indentations 300 $\mu \mathrm{M}$ apart were made in each layer (Figure 1).

The data obtained were statistically calculated using Analysis of Variance and Tukey's Test on the GraphPad Prism (v. 3.02) and GraphPad InStat (3.06) computer software. The significance level adopted was $5 \%$.

Chart 1. Description of the artificial teeth used.

\begin{tabular}{|c|c|c|c|}
\hline Brand & Composition & Manufacturer & Origin \\
\hline Artiplus ${ }^{\circledR}$ & $\begin{array}{c}\text { Polymethylmethacrylate, } \\
\text { ethyleneglycol } \\
\text { dimethacrylate, } \\
\text { fluorescent pigments }\end{array}$ & Dentsply Ltd. & $\begin{array}{c}\text { Petropolis, RJ, } \\
\text { Brazil }\end{array}$ \\
\hline Biotone ${ }^{\circledR} I P N$ & $\begin{array}{c}\text { Polymethylmethacrylate, } \\
\text { ethyleneglycol } \\
\text { dimethacrylate, } \\
\text { fluorescent pigments }\end{array}$ & Dentsply Ltd. & $\begin{array}{c}\text { Petropolis, RJ, } \\
\text { Brazil }\end{array}$ \\
\hline $\begin{array}{l}\text { Trilux }^{\circledR} \\
\text { Eurovipi }\end{array}$ & $\begin{array}{c}\text { Polymethylmethacrylate, } \\
\text { ethyleneglycol } \\
\text { dimethacrylate, Ormocer, } \\
\text { fluorescent pigments }\end{array}$ & $\begin{array}{l}\text { Ruthinium }^{\circledR} / \\
\text { Vipi Ltd. }\end{array}$ & Turin, Italy \\
\hline Bioform ${ }^{\circledR}$ & $\begin{array}{c}\text { Polymethylmethacrylate, } \\
\text { ethyleneglycol } \\
\text { dimethacrylate, } \\
\text { fluorescent pigments }\end{array}$ & Dentbras Ltd. & $\begin{array}{l}\text { Pirassununga, } \\
\text { SP, Brazil }\end{array}$ \\
\hline Natusdent $^{\circledR}$ & $\begin{array}{l}\text { Methyl methacrylate, } \\
\text { methyl-polymethacrylate, } \\
\text { ethyleneglycol } \\
\text { dimethacrylate, } \\
\text { fluorescent pigments, } \\
\text { organic dyes. }\end{array}$ & Dentbras Ltd. & $\begin{array}{c}\text { Pirassununga, } \\
\text { SP, Brazil }\end{array}$ \\
\hline
\end{tabular}




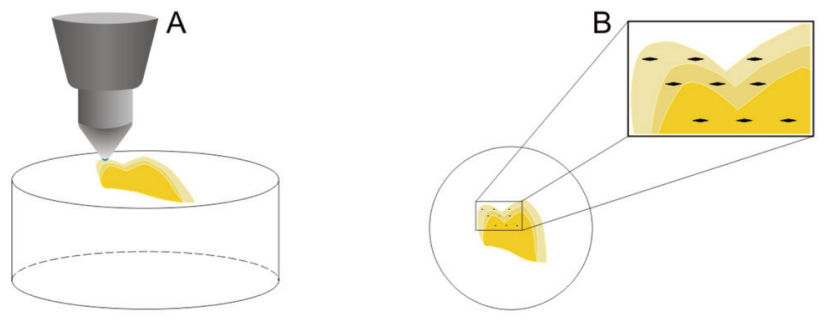

Figure 1. Illustration of the set-up for Knoop microhardness evaluation (A) in acrylic resin teeth, in which indentations were made in their different pressing layers (B).

\section{RESULTS}

The Analysis of variance demonstrated that the teeth tested did not show difference in microhardness in their first (outer) layer ( $p=0.355$, Figure 2A). In the second layer, however, Analysis of Variance and Tukey's test showed that Artiplus ${ }^{\circledR}$ teeth had superior values when compared to those by Natusdent ${ }^{\circledR}(p=0.018$, Figure $2 B)$. In the third layer, the same statistical tests indicated that the teeth Artiplus $^{\circledR}$ and Trilux ${ }^{\circledR}$ Eurovipi presented higher microhardness than the teeth Natusdent ${ }^{\circledR}(p<0.001$, Figure $2 C)$.
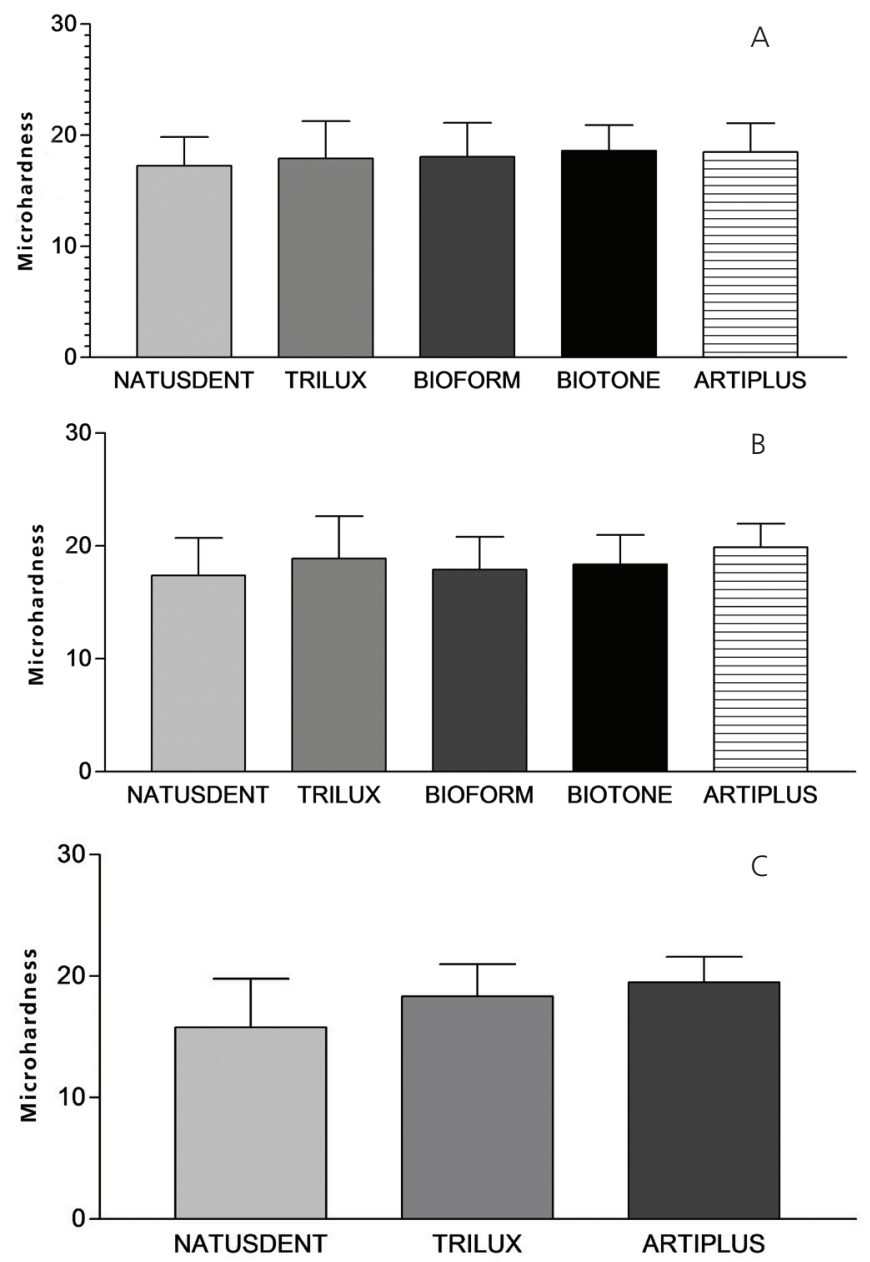

Figure 2. Knoop microhardness (in $\mathrm{Kg} / \mathrm{mm}^{2}$ ) according to commercial brands of the acrylic teeth in the first (A), second (B) and third (C) pressing layers.

\section{DISCUSSION}

The use of artificial teeth with properties such as good hardness and esthetics plays a pivotal role in the success of restorative treatment, since the maintenance of a stable occlusion, quality and comfort of mastication are dependent on such properties. In the present study, lower first molars were used because they are key of occlusion teeth and therefore extremely important for achieving a stable occlusal relationship ${ }^{9}$.

Teeth hardness of prosthetic teeth appears to have a direct impact on comfort, since wear resistance provides a stable occlusal relationship over time. The consequences of artificial teeth wear are loss of OVD with proportionally reduced masticatory efficiency, occlusal instability and the development of parafunctional habits ${ }^{7}$.

Theoretically, teeth that present lower hardness values absorb occlusal impacts better, just as harder teeth transfer high impacts through to the subjacent bone, causing bone resorption?. There are studies showing an association between wear and hardness ${ }^{10-12}$, as well as between mechanical strength and artificial teeth. ${ }^{13}$ In that context, it is possible to say that the analysis of microhardness, as a property with an impact on the performance of artificial teeth, is a valid method to evaluate the presence of different pressing layers. Indeed, in the only study comparing the pressing layers of acrylic teeth, microhardness was used as a method for analysis ${ }^{14}$.

In the present study, no significant difference in microhardness was found in the outer layer of the commercial brands tested. In fact, Winkler et al. ${ }^{3}$ compared brands of modified resin teeth (Bioform and Nuform) and concluded that none of them obtained results significantly superior to those from conventional acrylic resin. The same conclusion was reported by Rodrigues et al. ${ }^{15}$, who found no difference in tooth wear when comparing Biotone IPN and Trilux teeth, despite their different number of pressing layers. The findings of the present study are also in agreement with those by Assunção et al. ${ }^{16}$, who reported no significant difference in wear of Artiplus $^{\circledR}$ andTrilux ${ }^{\circledR}$ Eurovipi teeth compared to conventional acrylic teeth.

Studies on toothbrushing abrasion also reported no difference between artificial teeth made of conventional acrylic resin and those made from modified resin ${ }^{1,7}$.

The lack of significant difference between the types of acrylic resin teeth found in this study for the outer layer, however, contradict the findings by Khanna \& Aparna ${ }^{14}$. Those authors observed that all teeth with three pressing layers presented significantly higher 
values of microhardness than those with two layers. It is important to highlight, however, that the commercial brands with three layers contained composite resin with microparticles, which was not the case in any of the products tested in this study. Therefore, comparison between the studies is limited.

The results from the present study contradict those by Whitman et al. ${ }^{5}$, who reported that IPN reinforced resin teeth presented higher values of microhardness when compared to conventional acrylic teeth. A possible explanation for the different results obtained in their investigation is the fact that they stored their samples in water oralcoholic solution at 75\% for a week, whilst in this study no immersion solution was used. Considering that conventional acrylic resin teeth are more readily damaged in solvents than modified resin teeth ${ }^{5}$, the superior results can be justified in the context in which their experiments were conducted.

In the inner pressing layers, i.e., the second and third layers, difference was observed between the commercial brands, corroborating previous reports ${ }^{14}$. It is important to highlight, however, that the composition of the teeth tested by those authors was different to that of the teeth in this study.

It is possible that differences between commercial brands in the inner pressing layers may be of restricted relevance from the clinical viewpoint, since in order for the second and third layers to become exposed it would be necessary that the first layer was worn away. However, an

\section{REFERENCES}

1. Freitas KM, Paranhos HFO. Perda de massa de cinco marcas de dentes artificiais disponíveis no mercado após escovação com três diferentes dentifrícios. J Appl Oral Sci. 2006;1(4):242-4. 10.1590/S1678-77572006000400006.

2. Ekfeld A, Oilo G. Wear mechanism of resin and porcelain teeth. Acta Odontol Scand. 1989;47(6):391-9.

3. Winkler S, Monanky GE, Kwok J. Laboratory wear investigation of resin posterior denture teeth. J Prosthet Dent. 1992;67(6):812-4.

4. Pero AC, Marra J, Polatto CA, Barbosa DB, Compagnoni MA. Resistência de união entre dentes artificiais e resinas acrílicas para base protética. Polímeros. 2007;17(3):194-200. doi: 10.1590/S0104-14282007000300007.

5. Whitman DJ, Mckinney JE, Hinman RW, Hesby RA, Pelleu $\mathrm{GB}$. In vitro wear rates of three types of commercial denture tooth materials. J Prosthet Dent. 1987;57(2):243-6. doi: 10.1016/0022-3913(87)90154-5. eventual exposure of the second layer could occur in cases where a significant occlusal adjustment may be required, which is an aspect that may be considered when choosing from different brands of artificial teeth.

Based on the result from this study, it is valid to question whether there would be any purpose for several pressing layers in artificial posterior teeth other than esthetic or better occlusal design. Nonetheless, considering that, in addition to microhardness, the choice of acrylic resin teeth must be based on other properties, further studies are required in order to widen the understanding of the benefits of different pressing layers.

\section{CONCLUSION}

In the outer layer, the microhardness of artificial teeth was similar for all tested brands. Only in the second and third layers was a difference observed between the brands, where teeth by Artiplus ${ }^{\circledR}$ presented higher values of microhardness than those by Natusdent ${ }^{\circledR}$.

\section{Collaborators}

RS BAPTISTA was responsible for the research and write-up. GD MENDES participated in the statistical analysis and manuscript writing. ME MIRANDA and CP TURSSI were the supervisors and also participated in the writing of the paper.

6. Lindquist TJ, Ogle RE, Davis EL. Twelve-month results of a clinical wear study of three artificial tooth materials. J Prosthet Dent. 1995;74(2): 156-61.

7. Brigagão VC, Camargo FP, Neisser MP. Avaliação in vitro da resistência ao desgaste de dentes artificiais. Cienc Odontol Bras. 2005;8(3):55-63.

8. von Frauhofer JA, Razavi R, Khan Z. Wear characteristics of highstrength denture teeth. J Prosthet Dent. 1988;59(2):173-5.

9. Turano JC, Turano LM. Fundamentos de prótese total. 8a ed. São Paulo: Editora Santos; 2007.

10. Suzuki S. In vitro wear of nano-composite denture teeth. J Prosthodont. 2004;13(4):238-43. doi: 10.1111/j.1532849X.2004.04043.x.

11. Abe $Y$, Sato $Y$, Taji T, Akagawa $Y$, Lambrechts $P$, Vanherle $G$. An in vitro wear study of posterior denture tooth materials on human enamel. J Oral Rehabil. 2001;28(5):407-12. doi: 10.1046/j.13652842.2001.00670.x. 
12. Zeng J, Sato $Y$, Ohkubo $C$, Hosoi $T$. In vitro wear resistance of three types of composite resin denture teeth. J Prosthet Dent. 2005;94(5):453-7. 10.1016/j.prosdent.2005.08.010.

13. Suwannaroop P, Chaijareenont P, Koottathape N, Takahashi $H$, Arksornnukit $M$. In vitro wear resistance, hardness and elastic modulus of artificial denture teeth. Dent Mater J. 2011;30(4):461-8. doi: 10.4012/dmj.2010-200.

14. Khanna G, Aparna IN. Comparison of microhardness of three types of acrylic artificial denture teeth: an in vitro study. J Orofac Pain. 2013;3(3):181-5.

15 Rodrigues AR, Vanzillotta PS, Silva Figueiredo CM, Lima RM, Rodrigues Filho HS, Gouvêa CVD. Avaliação in vitro da resistência à abrasão de dois dentes de resina acrílica melhorada utilizados na confecção de próteses removíveis. Rev Bras Odontol. 2011;68(1):25-8.
16. Assunção WL, Barbosa DB, Goiato MC, Tabata LF, Gennari Filho $\mathrm{H}$. Evaluation of the wear rates of eight different brands of artificial resin teeth. Cienc Odontol Bras. 2005;8(4):6-12.

Received on: 13/6/2013

Final version resubmitted on: 8/11/2013

Approved on: 3/12/2013 